\title{
PDA (Personal Digital Assistant) Effectiveness Towards Music Learning Results
}

\author{
Arin Pradikasetya Rahmawati ${ }^{1, *}$ Kun Setyaning Astuti ${ }^{1}$
}

\author{
${ }^{I}$ Master Programme, Yogyakarta State University, Yogyakarta, Indonesia \\ *Corresponding author.Email: pradikaarin17@gmail.com
}

\begin{abstract}
Music learning activities cannot be separated from theoretical learning processes and outcomes. In order to support and improve learning processes, interesting learning media are needed. The purpose of this study is to determine the effectiveness and the role of the PDA (Personal Digital Assistant) in supporting music learning. This is Research and Development (R\&D) with the Borg and Gall model employing 10 steps namely (1) Potential and Problem Identification; (2) Data collection; (3) Product Design; (4) Product Manufacture; (5) Validation I; (6) Revision I; (7) Validation II; (8) Revision II; (9) Test of Usage (Pretest and Posttest); and (10) Distribution. This study used a Sequential Exploratory model. The sample was selected by means of Purposive technique because the number of population and sample are the same (27 students). Retrieval of data was conducted by using the questionnaire technique (multiple choices questions). In the pretest, the average score was 58.7 while 71.2 average score was obtained in the posttest. Data was calculated using Wilcoxon Analysis. The final result of the Wilcoxon test (Asymp Sig 2 Tailed) is 0.00 then with the provisions of Asymp Sig $<0.05$, the hypothesis is accepted. This result suggests that PDA demonstrates high effectiveness in supporting and improving theoretical music learning activities and outcomes. Keywords - PDA, Digital, Music, Effectiveness, Mobile Phone.

\section{INTRODUCTION}

Music education is no less important than education in general. Music is believed to have a positive effect on those who are aware of it, as Bassano said that "In the emotional realm, music with clear melodies refreshes feelings - helps us release stresses and allows us to find ourselves by recognizing emotions and feelings. This enables us to develop expression and creativity [1]. This description reinforces the importance of music education in a life where listeners can explore and develop their creativity after enjoying music.

The role of notation in music learning is allegedly very important, especially if the student is lacked of the ability in relation to tone sensitivity. Notation will make it easier for students to play songs with their respective instruments so that the structure and sequence of learning can be carried out smoothly without obstacles for reasons of not understanding the notes that must be played. The results of an interview with Fitrianingtyas, a piano teacher at a music school in Malang, said that "Teachers can explain more detailed material than just auditory so there is a visual guidance when students are lack of sufficient musicality." Another opinion expresses the importance of the notation that "for documenting learning,

and explained by the teacher", Garini, a music school violin teacher in Malang. On another occasion, an interview was conducted with Yulindacesa regarding the function of notation for students and teachers in learning that "Equally to increase tone sensitivity, an initial introduction to sounds, even techniques if music notation in this case concerns the technique. The main thing is the tone and beats in the notation, if it is already known by both, the learning process will be easier and more exciting". Some of these opinions reinforce that notation is very important as a process to facilitate music learning.

Music learning as well as general learning will be more flexible and easily accepted if there is media as a supporting tool in the delivery of material by educators. The importance of media factor is supported by the Mukminan's statement that "... no longer limited by the dimensions of space and time, so that it can be accepted by learners well, easily, and extensively, as well as creating fun, flexible learning in the dimensions of time, space, and developing the potential of participants students both individually and communally "[3].

Asyar's opinion that states "the function of the media as a source of learning, that is, as a distributor, a conveyor, a liaison message / knowledge from students to learners", thus the sentence excerpts further reinforce that learning media is really
\end{abstract} students will always remember something that was conveyed 
needed and has positive benefits for people who want or are learning.

21st Century technology is not difficult to exploit, there have been many developments in aspects of technology such as transportation and communication devices where almost all of these devices are all digital and online. One examples of sophisticated communication tools today is Android, which is a mobile operating system with the most complete features. This is supported by Supardi who revealed that "The most widely used operating system on tablets currently available is Android, the reason for the importance of using Android is to have features that are fairly complete, high-performance, open and free" [5].

One effort to direct the cell phone on the positive side is to insert applications related to learning material on the cellphone. On this occasion, the developer will utilize a cellphone that has an Android operating system as an effective and flexible learning medium in the Basic Theory Notation material.

Application of Basic Theory of Notation contains eight main material namely Notation, Value of Notation, Dynamics, Tempo, Articulation, Chord, Octave and Circle of Fifth. In addition to the main subject, there is also a test that contains a collection of questions related to the material to test the understanding of student after learning.

Music notation is a basic aspect that is very helpful in the process of learning music, both for students and teachers. Student scores on music theory are lacking, thus hampering the implementation of structure in learning. The importance of notation in music learning is fundamental, this development is carried out to assist teachers and students in delivering and absorbing material. This developed application was allegedly able to help and increase student grades in relation to notation theory. Modern technology including cell phones with Android operating systems can be used as a learning tool, not just to operate games, and just communicate. To maximize the benefits of this application, it is expected that the next developer will expand the material because there are only eight main topics available, namely notation, notation value, dynamics, tempo, articulation, chord, octaves, and Circle of fifth.

Knowledge is not only limited to writing, so it needs to be developed in other forms contained in this application, namely narrative audio which will help students or teachers to learn the material without having to read. Application of Basic Theory Notation can only be installed on smartphone with the Android operating system. The research involving students to test the influence before there was media and after media was only conducted on 27 students in one music school in the city of Malang.

Learning media is a device that has a positive function in learning. Achievement of learning outcomes can be helped by the media where the process of delivering material is not only done when the teacher and students meet. There is a chart that explains the position of the media in the delivery of learning material as follows.

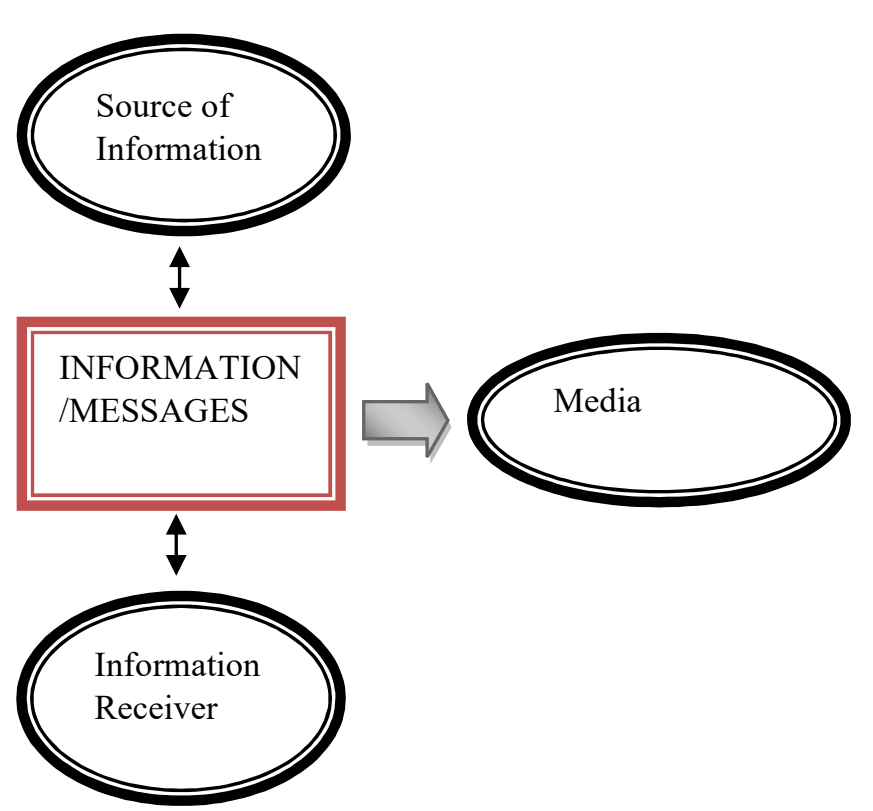

Figure 1 Components in the Communication Process [5]

The chart explains that the conveyor of communication in this case is material between students and teachers, which is mediators to help the process namely the availability of learning media. It is the importance of learning media so that when teaching without media is not effective.

This learning application is based on Android where there are several versions, as stated by Supardi $(2012,6)$ that "Android Beta, version 1.0, version 1.1, version 1.5 (Cupcakes), version 1.6 (Donuts), version 2.0 (Eclair), version 2.2 (Froyo), version 2.3 (Ginger-Bread), version 3.0 (Honeycomb), and version 4.0 (ICS) ".

Learning media consists of several types, namely visual, audio, audio-visual, and multimedia. This Basic Theory Notation application is included in the Multimedia type where there is a merger between the audio and visual types. Audio in the media is shown in narration and pitches, while visuals are shown in the presence of interesting images and designs in it. Malik and Argawal express the meaning of multimedia as follows.

Multimedia facilitates mastering basic skills of a student by means of drill and practice. It helps in problem solving by means of learning by doing, understanding abstract concepts, provides enhanced access for teachers and students in remote locations, facilitates individualized and cooperative learning, helps in management and administration of classroom activities and learning content, and simulates real life problems handling environments. Multimedia Technology is used and 
experimented by various educational institutions of all levels all over the world in their own designed modes [2].

The above understanding clarifies the flexibility, usability, and benefits of learning media. The use of multimedia can be classified in the learning system with M-Learning (Mobile Learning). M-Learning is a learning process by utilizing gadgets, smartphones or other small devices. As Behera stated, "Mobile learning, sometimes called m-learning, is learning accomplished with the use of small, portable computing devices. These computing devices may include: smart phones, personal digital assistants (PDAs) and similar handheld devices [1]. The statement strongly reinforces that the level of learning flexibility by using a PDA (Personal Digital Assistant) including Android Smartphone will be higher than other conventional learning.

\section{METHODOLOGY}

\subsection{Data}

Data was collected for 7 teachers in various music schools in Malang in order to dig up information (interviews) about the importance of notation in art learning. Next is the validation data from two experts namely material experts and media experts using a questionnaire system as a measure of the feasibility of Basic Notation Theory Application. The data is then obtained through a trial which is divided into 2 stages namely Pretest (Before using media) and Post-test (After using media). The Pretest and Post-test stages used as many as 27 students.

The results of the interview are used as a basis for making decisions on the importance of notation in music learning. Validation data is used to measure the validity of applications developed. The validation questionnaire contains the media assessment benchmarks which were drafted by the developer themselves and corrected by the validation expert. While the trial data (Pretest and Post-test) use a question sheet containing multiple choice answers and calculated using the average formula (Mean).

\section{$2.2 \quad$ Methods}

This development uses a Sequential Exploratory model where the excavation of problems and solutions is done by Qualitative and Quantitative techniques. The method used is R\&D (Research and Development) from Sugiyono which has been modified according to the needs and abilities of researchers. These methods include finding Potential and Problems, Data Collection, Product Design, Product Manufacturing, Validation
I, Revision I, Validation II, Revision II, Trial Use (Pretest and Posttest), and Distribution (Publication) [6].

Potential and problems are useful in gathering information about problems and solutions in the field by conducting interviews with several music teachers in various music schools in Malang. In this first stage, a Pretest was also conducted to measure students' abilities in understanding the material. Data collection is carried out to assist in the product design process in the form of library data for material content in the application. The material is obtained from many national print books and journals or international articles. Once the material has been collected, then the product design is done as a picture of the original product. The process of making products is carried out by experts in the field of multimedia.

The finished product in format (.apk) is validated by material experts and media experts in the first stage, then the product is revised after being from the validator. This revision process is still being carried out by multimedia experts, so that after the revision the product is revalidated in the second stage and revised in the last stage. Products that have been revised in the final stage and ready for use are then tested on students who are divided into two stages, namely pretest and post-test. The products that have been tested are then mass produced by uploading them to the Online Market on every Android named Google Play Store with the keyword 'Basic Theory of Notation'.

The method in this development uses R\&D (Research and Development) modified by Sugiyono as follows [6].

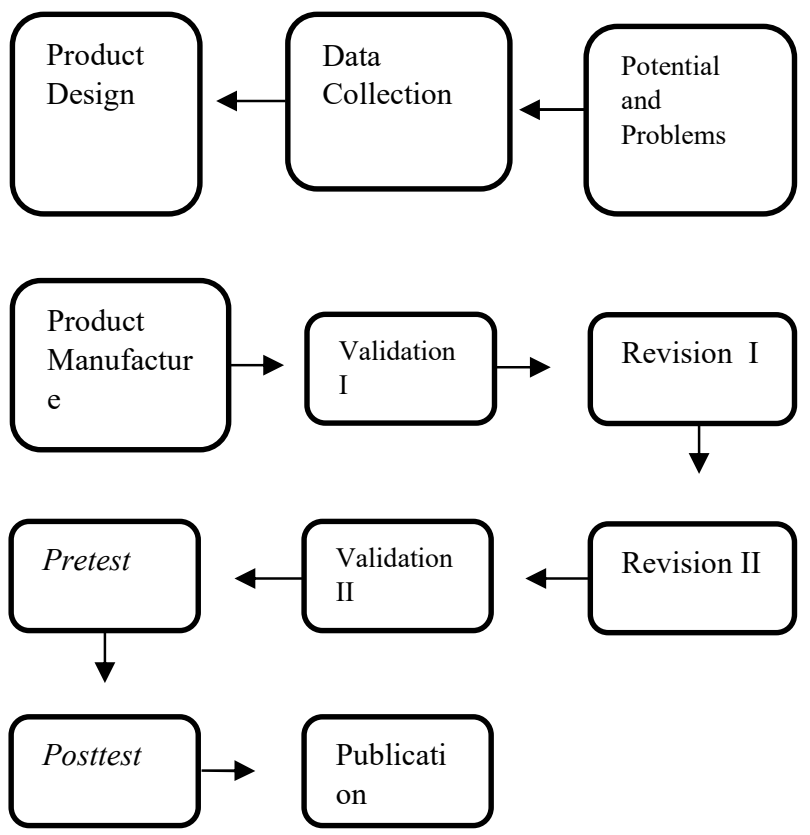

Figure 2 Modified by Sugiyono 
The chart above is a step taken by the researcher with a slight modification of Sugiyono's original procedure. The modification was made to adjust the needs, abilities, and time constraints of the researchers.

\section{RESULTS AND DISCUSSION}

The study was conducted carefully and produced data in the form of the results of the pretest and post-test that were ready to be analyzed using quantitative analysis. The data obtained in the study can be seen in table I below.

Table 1 Achievements of pre-test and post-test value

\begin{tabular}{|c|c|c|}
\hline \multirow{2}{*}{$\begin{array}{l}\text { Student } \\
\text { Number }\end{array}$} & \multicolumn{2}{|c|}{ Score } \\
\hline & Pre-test & Post-test \\
\hline 1. & 5.0 & 7.5 \\
\hline 2. & 6.0 & 7.0 \\
\hline 3. & 5.5 & 7.0 \\
\hline 4. & 5.5 & 7.0 \\
\hline 5. & 5.0 & 6.5 \\
\hline 6. & 5.5 & 7.0 \\
\hline 7. & 6.0 & 7.5 \\
\hline 8. & 6.0 & 7.0 \\
\hline 9. & 5.5 & 7.0 \\
\hline 10. & 5.5 & 7.5 \\
\hline 11. & 5.5 & 7.5 \\
\hline 12. & 5.0 & 7.5 \\
\hline 13. & 6.0 & 7.5 \\
\hline 14. & 6.0 & 8.0 \\
\hline 15. & 6.0 & 7.5 \\
\hline 16. & 6.5 & 7.0 \\
\hline 17. & 6.5 & 7.0 \\
\hline 18. & 5.5 & 6.5 \\
\hline 19. & 6.0 & 6.5 \\
\hline 20. & 6.0 & 7.0 \\
\hline
\end{tabular}

\begin{tabular}{|c|c|c|}
\hline 21. & 6.0 & 6.5 \\
\hline 22. & 6.0 & 7.0 \\
\hline 23. & 6.5 & 7.5 \\
\hline 24. & 5.5 & 7.0 \\
\hline 25. & 6.5 & 7.0 \\
\hline 26. & 6.5 & 7.5 \\
\hline 27. & 7.0 & 7.0 \\
\hline
\end{tabular}

The above data is then analyzed using quantitative methods with Non-Parametric statistics namely the Wilcoxon Test. Analysis of the data obtained at the pretest stage found that the average results obtained from 27 students was 58.70. The next stage is the post-test with an average grade of 71.20. Details of the analysis phase can be seen in the following SPSS Output table:

Table 1 SPSS data output for pretest and post-test

\begin{tabular}{ccc|c|c} 
& & N & Rean & Rum of \\
Posttest - Pretest & Regative & $0 \mathrm{a}$ & .00 & .00 \\
& Ranks & & & \\
\cline { 2 - 5 } & $\begin{array}{c}\text { Positive } \\
\text { Ranks }\end{array}$ & $26 \mathrm{~b}$ & 13.50 & 351.00 \\
& & & \\
\hline & Ties & $1 \mathrm{c}$ & & \\
\hline Total & 27 & & \\
\hline
\end{tabular}

The data above clearly describes various values including Negative Ranks, Positive Ranks, and Ties. Negative Ranks consist of the number 0 in column $\mathrm{N}$ (number of students) which means that there is no decrease in scores experienced by students from the pretest to post-test stages. Positive Ranks explain the positive difference in scores obtained by students from the pretest to post-test stages. In the Positive Ranks column, 26 students were found to have improved scores which had an average increase (Mean Ranks) of 13.50 and the number of positive rankings or Sum of Ranks was 351.00. The final analysis column is the Ties column explaining the amount of similarity in student scores obtained after doing the pretest and post-test. The value of the Ties obtained is 1 , so it can be seen that there is one student who did not experience an increase or decrease in test scores. 
The next analysis is to determine the correctness of the hypothesis or draw conclusions from the data obtained using two conditions namely "If the value of Assymp. Sig $<0.05$, then Hypothesis Accepted" and "If the value of Assymp. Sig $>0.05$, then Hypothesis Rejected".> The results of the "Test Statistic" output to determine the conclusions of the study can be seen in the following table.

Table 2 Statistic test

Post Test - Pre-Test

\begin{tabular}{lr}
\hline $\mathbf{Z}$ & $\mathbf{- 4 . 4 9 4 b}$ \\
\hline Asymp. Sig. (2-tailed) & .000
\end{tabular}

Based on the "Test Statistics" output, it is known that the Assymp.Sig. value ( 2 Tailed) is worth 0,000 . Because 0.000 is less than 0.05 , it can be concluded that "Hypothesis is Accepted" which means there is a difference between the pretest and posttest scores, so it can be concluded that "There is a good influence in the use of PDA (Personal Digital Assistant) on learning outcomes about learning the art of music".

\section{CONCLUSION}

The results obtained from the trial show that the media has a good influence as evidenced by the increase in grades obtained by students, so it can be concluded that PDAs can be used as media that can make learning more interesting and flexible and can be done anywhere and anytime in accordance with the wishes of students. The increased ability and the difference in value obtained between pretest and posttest proves that PDAs can be utilized and succeed in increasing the value of students' knowledge.

\section{REFERENCES}

[1] Bassano, Mary. "Music and Colour: Terapi Alternatif.” Yogyakarta: Glosaria Media (2014).

[2] Behera, Santosh Kumar, and West Bengal-INDIA Purulia. "M-learning: a new learning paradigm."

International Journal on New Trends in Education and Their Implications 4.2 (2013): 24-34.

http://www.ijonte.org/FileUpload/ks63207/File/2013.2.com plete.pdf\#page $=31$

[3] Malik, S., and A. Agarwal. "Use of multimedia as a new educational technology tool-A study." International Journal of Information and Education Technology 2.5 (2012): 468. DOI : https://doi.org/10.7763/ijiet.2012.v2.181
[4] Mukminan. Teknologi Pendidikan Untuk Peningkatan Kualitas Pembelajaran [Educational Technology to Improve Learning Quality.]. Makalah disajikan dalam Seminar Nasional Teknologi Pendidikan, Prodi S2 Teknologi Pendidikan Fakultas Keguruan dan Ilmu Pengetahuan, Universitas Tanjungpura, Pontianak. 2012.

[5] Asyhar, Rayandra. "Kreatif mengembangkan media pembelajaran." (2012).

[6] Supardi, Yuniar. "Sistem Operasi Andal Android [Reliable Android Operating System]." Jakarta: PT Elex Media Komputindo (2012).

[7] Sugiyono, Metode Penelitian Kuantitatif. "Kualitatif, dan Kombinasi (Mixed Methods) [Quantitative Research Methods. "Qualitative, and Mixed Methods]." Bandung: Alfabeta (2016). 